European journal of American studies

Special Issue: Truth or Post-Truth? Philosophy, American Studies, and Current Perspectives in

Pragmatism and Hermeneutics

\title{
Being True, Sounding False
}

John T. Lysaker

\section{OpenEdition}

\section{Journals}

Electronic version

URL: https://journals.openedition.org/ejas/15592

DOI: 10.4000/ejas.15592

ISSN: 1991-9336

Publisher

European Association for American Studies

Electronic reference

John T. Lysaker, "Being True, Sounding False", European journal of American studies [Online], 15-1 | 2020,

Online since 11 May 2020, connection on 08 July 2021. URL: http://journals.openedition.org/ejas/

15592 ; DOI: https://doi.org/10.4000/ejas. 15592

This text was automatically generated on 8 July 2021 .

Creative Commons License 


\title{
Being True, Sounding False
}

\author{
John T. Lysaker
}

"For all men live by truth and stand in need of expression."

"The Poet," Ralph Waldo Emerson

1 What follows explores a very particular thought. Philosophy's native realm is error. It is born there, and error is where it lives. And should it die, and I presume it can and will, philosophy will feel more at home in the company of failure than success.

2 "Explore" is perhaps misleading. What follows less mines the thought, as if it were a stable vein of ore, than keeps pace with it, or tries to, and from various angles-as if it were on the move. Or not "as if." It is. On the move.

3 The character of what follows is that of an essay, a venture that embraces its partiality in order to expand it, tracks the mote in order to survey its orbit and the alignments achieved along the way. In this, I refuse the temptation of a certain kind of objectivity, one that attempts to secure itself by purging the subjective. But this is not to say that I simply accept the subjective in the sense of defering to it, as if what dawned on me were sufficient, even for me or concerning me. Rather, here the partial becomes the basis of an experiment of sorts, one that establishes conditions in the hope of initiating a chain of reactions.

4 In favoring the experimental, this essay is neither simply personal nor impersonal. The experiences expressed here (in keeping with the sense of "expression" operative in Emerson), are thus as much a matter for you as for me, both in the languages enacted and in how they have been shaped. Moreover, their aim remains a certain kind of truth, one I hope to clarify along the way.

we arrive again an innumerable

entering as if from another life

"Sea of Lanterns," Anne Michaels

Philosophy's native realm is error. It is born there, and error is where it lives. And should it die, and I presume it can and will, philosophy will feel more at home in the company of failure than success. I offer this thought in earnest even as I feel its ironies ripple. How, after all, does philosophy uncover-is "discover" too strong?-and mark its limits without casting them as insights, thereby converting humility into self- 
possession? And what happens as the claim recoils on its own assertoric character? Is performative contradiction a dead end or the first contortion in a transformation? How do I relate to myself in claiming to understand the sentences with which I begun? In what way is this an act (perhaps just a pursuit) of self-knowledge? And what do those sentences offer you, my varied addressees? "Is he serious," you might rightfully ask. Living serious, I wish one could say.

Philosophy's native realm is error. This thought is something of a touchstone for me, or rather, a thoroughbass against which other thoughts resound-some quite singular, others developed across paragraphs, still others requiring a whole text to present, maybe a handful strung across (and between) several ventures. And because it is so dear, so intimate to what I take philosophy to require of me, I find myself compelled to register it, recounting why I accept it, and to use that acceptance to reflect on what philosophy has to offer, and how "truth" factors into that provisional address.

7 Learning is a humbling affair. It indicates that one was either mistaken or ignorant. And learning is not alone in this intimacy with error. Surprise is also bound to mistakes. What seizes our attention exposes our ignorance or some misstep-how cold the water is, how hot the dancing lights, how unlike the two sisters, how differently certain texts read thirty years later. Even experience is something like a child of error. Were our anticipations always right, I doubt we would notice, and I doubt that anything like "noticing"-one name for one movement between anticipation and occurrencewould ever have evolved. As Hegel has it, experience involves a self-surpassing movement, and what is surpassed is usually-always in my experience-an inadequate anticipation of what in fact appears. (As Emerson has it, experience is just this ongoing movement within a broad, multi-surfaced expanse of selves and world, though many travel innocently-or in conformity-as if they were unable to bear the task of relating to themselves and reworking their accords and discords.)

Where would we be without error? I doubt we would be in-the-world as we are. To be clear, my point is not Heidegger's when he argues that we are ensnared in the everyday, and thus forgetful of our ownmost possibility for being, or, in a related argument, that our absorption in the world of beings renders us forgetful of the clearing event that enables us to be-there amid beings. I have something more prosaic in mind. Were our relations with beings mostly adequate, the character of our being would be quite different. Perhaps we would hover like Rilke's angels, fruhe Gegluckte, "early successes," Gelenke des Lichtes, "joints of light," catching, like mirrors, the rushing world and their own rush therein, presuming, that is, reflexion without friction is possible.

9 But not to worry. The earliest scenes of instruction envelop us in error. As awareness dawns, the world expands around our tiny hands, legs and mouths. Return to childhood haunts-the woods behind the house, the swampy stream to its left. If you're like me, you'll be startled. They seem so petite. But once they were too vast to survey: dandelion and skunk cabbage, bull frog and toad, chipmunk, white tail deer, though variously, depending upon the season, which was itself a marvel-spring peepers despite the lingering snow. Not that such a site has been exhausted. That would just be another error. Even keeping to the deceiving glow of universals, the scenes are rich beyond our ken: pseudacris crucifer, symplocarpus foetidus, pine and birch in spring and fall, ground water buried deep but seeping, granite and shale in Ossining, possibly from assunung, meaning "place of stones" in a Lenape dialectic of Algonquin called Munsee, spoken by 
those also called Munsee, though several names swirl around the land I have in mind, such as Wappinger and Kitchawanks (Grumet 117).

"We can never surprise nature in a corner," Emerson writes, "never find the end of a thread; never tell where to set the first stone" (Nature, Addresses, Lectures 124). It isn't just that nature likes to hide. It also likes to show itself variously across a vast, changing yet interlocked complexity, synchronous in certain ways, asynchronous in others-rock and water, soil accruing, nurse logs and ferns, but also persons and people, which in my corner of Ossining, New York, involved migrations, invasions, microbes and murder. Our recurring introduction to the world is awash in this surfeit, and so, over time, anticipation and presumption open into a desire to know, from which philosophy springs.

11 But what about wonder? Yes, wonder (or astonishment), which Aristotle aligns with philosophy-thaumazein (Metaphysics 982b.11-12). But philosophy only commences amid the astonishing because we are oriented toward the world knowingly. Other replies to astonishment are possible, after all: flight, worship, violence. But philosophy responds with what was already underway, inquiry, asking, "what has occurred, how, and to what end?," questions that arise because the astonishing confounds.

I have turned back into these imagined, inceptual scenes of surprise and astonishment because they show, in part, that we become philosophical because we err. But error haunts what follows as well. An eventual inadequacy seems to await each philosophical venture. Even its most illustrious practitioners warrant correction. In fact, the greater the figure, the more powerful the counter-stroke: Aristotle to Plato, Spinoza to Descartes, Hegel to Kant. My point is not that the squabbles of the philosophers are unresolvable. Aristotle demonstrates convincingly that ethical deliberation is insufficiently oriented by definitions of the good überhaupt. Spinoza rightly argues that the search for truth criteria opens onto an infinite regress. And Hegel was right to historicize the patterns of knowing (and doing) that propel natural consciousness. Nothing convinces for very long, and many exquisite moments are born in the realization and demonstration of another's shortcoming.

13 Permit me a more extended example. Rorty's insistence that vocabularies are not truth-functional is less compelling than it once seemed, at least to me. As he understands them, vocabularies (e.g. Newtonian mechanics, quantum theory, psychoanalysis), can only be tested in a circular manner, namely, by presupposing their own domain of objects (say a world of wave and particle, or the unconscious and its sublimations). And he concludes that vocabularies are invented or evolved rather than discovered, and that such inventions or fictions enable the kind of discoveries that can be hammered out in ways that are true or false, namely, at the level of sentences.

14 I once affirmed this thought but it now seems unconvincing. Vocabularies do not arise independently of discoveries, and so the truth (and falsity) of various discoveries is part of the mortar that holds together a vocabulary's outer and inner walls. (Newton did not awake one morning to Newtonian mechanics, and Saul opened his eyes as Paul only because he was already in the thick of a messianic, theistic context.) And that is no less true if we drop "invention" in favor of cultural evolution. The process of epistemic change remains bound to discoveries and their contestation-an anomaly is a discovery after all, and one communicated by way of a finite set of truth claims (as opposed to an entirely new paradigm). It is thus not the case that paradigms die all at once. Instead, they die in part because they are repeatedly cut by receive by truth-functional blades 
and so begin to wobble. Secondly, and more importantly, vocabularies must maintain some kind of phenomenological fit if one is going to act on them. Rorty often invokes psychanalysis as the kind of invention that could fuel self-creation rather than selfdiscovery, although discoveries become possible once we accept the invention. But is it just a matter of accepting the vocabulary (or not) without reference to experience's epistemic valence?

Imagine a continuum marked by two extremes. One involves an apprehension that leaves nothing unanticipated, including the logic and character of anticipation-call this, after Hegel, absolute knowledge. At the other, nothing that has been anticipated occurs-call this absolute error. How would you respond to a vocabulary that approached absolute error? Not just that you kept misinterpreting your dreams. There were never any "dreams" to interpret, and so the invitation to do so found nothing to address. Not that you found the "death instinct" odd, but that desire itself, sexual or otherwise, seemed profoundly alien? Rorty's pragmatism invites us to accept and reject vocabularies depending on our interests. But a vocabulary approaching absolute error would prove unable to further any interest, or include a term as felicitous (if vague) as "interest" or "vocabulary" for that matter.

My point is not that Rorty's point is a wholesale error. If anything, it works well enough to run counter to the point he wants to make. More specifically, his distinction between sentence and vocabulary has some traction, that is, it brings us into a working relation with some swath of our experience. It helps me think about different approaches to similar phenomena, something I might miss if I kept to the level of sentences. Yes, "vocabulary" is a metaphor in these contexts, but it is somewhat apposite to the phenomena in question, that is, "true." I no longer believe, therefore, that one can altogether detach vocabularies (or paradigms, or webs of inquiry, or epochs of being, or discursive regimes, or patterns of inquiry) from epistemic considerations. (In fact, I'm beginning to question the expediency of that whole range of concepts. Ironically, like the notion of the conceptual scheme, they seem epistemically hubristic. But that is a matter for another time.)

17 To be clear, binding philosophy to something like the desire to know does not settle the question of the value of truth, nor abandon care of the self for know thyself. Addressing sexual phenomena, one might, like Foucault, wonder whether discourses of pleasure (the ars erotica) are not preferable to those that address sexuality only in order to know it (the scientia sexualis). And one might, like Nietzsche, believe it preferable not to know everything that our friends think about us, and allow such realizations to temper our will-to-truth. But, even in denying truth a seat among the greater goods, it remains a value. No discourse of pleasure can operate wholly outside epistemic considerations without dissolving into an unordered collection of directives that risk significant (unintended) pain.

18 I have been arguing that philosophy is destined for error. The world's dynamic complexity and the partiality of our movements through it (hence our access to it) lead me to this conclusion, as do the various oversights that define the history of philosophy. We thus know that our substantive commitments will prove insufficient. The curtain never rises, the beach washes away at the point of arrival. Philosophy is not just born in error. Error is its native realm. But my recounting of Rorty hoped to do double duty. Philosophy cannot take refuge in discourses indifferent to truth. Their value to us is bound in part to the traction they provide, which is what I always took 
James to mean, when he claimed that the true is "only the expedient ["in the long run and on the whole"] in our way of thinking," meaning, it is that which secures our footing (106). And while the modifier "only" is hasty, one could hear it this way. We grant certain claims the status of "truth" because they fit the scene in which they are uttered. That is what we mean when we say of some remark that it is "true." "To agree in the widest sense with a reality," James writes, "can only mean to be guided either straight up to it or into its surroundings, or to be put into such working touch with it as to handle either it or something connected with it better than if we disagreed. Better either intellectually or practically" (102). But today's working touch is tomorrow's clumsy grasp, and so even what merits the approbation "true" must remain open to reassessment. "The truth of an idea is not a stagnant property inherent in it. Truth happens to an idea. It becomes true, is made true by events. Its verity is in fact an event, a process" (97). Rather than simply valorizing expediency, James's "only the expedient" keeps us on our toes, and precisely because error awaits.

words that taste of an answer

"Sea of Lanterns," Anne Michaels

Error. Truth. They delimit an expanse within which philosophy finds itself. But what kind of insight is this? And what is a fitting way to accept it (presuming you do)? Born in the midst of error, philosophy cannot rest in its thrall, at least not simply. One always seeks an advance of sorts, even in acknowledging one's limits. In Giving an Account of Oneself, Judith Butler stresses again and again that our accounts are riddled by opacities with respect to desire and influence, both personal or cultural. Our accounts of ourselves are thus fragmentary. But such an observation occurs within an account of oneself (an account of accounting), and it is offered as a kind of selfknowledge, which only thickens the question.

The last paragraph of Emerson's "Experience" commences with the following: "I know that the world I converse with in the city and in the farms, is not the world I think. I observe the difference, and shall observe it" (Essays: Second Series 48). Tenuous as it is, this sentence marks one of my footholds in philosophy, despite (and because of) how it steadies itself on so much more than inferential ligature. The thought is too complex to fully unpack, so I'll focus on what chiefly pertains to what I hope is now our context. Emerson claims to know something observable: a discrepancy operates between his thoughts and that to which they refer, namely the world to which he belongs by way of conversation. But, in an inversion of Fichte, Emerson converts the thought into a practical stance-I shall observe it, as one might a holiday or sacred space (rather than proceed as if the world I converse with were a moment in my self-presentation). Or, it might be better to say that Emerson's comportment is transfigured in his realization of the discrepancy, which he elects to carry into future conversations.

In the manner of an Emersonian observance-that is how I grasp the kind of selfknowledge that registers our intimacy with error and the dependence of our bearings upon truth. That is how I understand James when he claims that the true is "only the expedient ["in the long run and on the whole"] in our way of thinking."

In 2018, Stanley Cavell died at the age of 91. But that hasn't stopped me from running into him again and again. At the moment, I am resisting skepticism as a definitive philosophical position without supposing to have overcome it or caught it out in contradiction, thematic or performative. Error not only awaits our ventures, it generates them as well, and to live in acknowledgement of that is to be poised for 
redirection, what Emerson would term abandonment, which captures nicely how a change in view moves away from some commitments toward others, and with the kind of affirmation that occurs when the validity of what we rush toward cannot be secured ahead of time. ("Reckless abandon" the risk averse say; "joyful abandon" replies the romantic.)

between the sea

and the dream of the sea

"Sea of Lanterns," Anne Michaels

"But," you might suggest, "truth has more than one sense, no? Thus far you have limited it to a kind of adequation." A fair point. Heidegger has argued that propositional truth presumes an event of disclosure in which something like a sentence or belief can be said to be adequate or inadequate to its Sache, the matter at hand. And he regards that event as a kind of originary truth. Now, one might regard this as a stretch, that is, a poor metaphor, particularly since truth as disclosure seems epistemically indifferent. Disclosure occurs with the true and the false, and realizing that, that is, agreeing with Heidegger, doesn't improve one's chances of avoiding error. However, the event of disclosure remains part of truth's occurrence, the event of verity, in James's words, and so, an account of truth proves false, in the sense of incomplete, if it fails to acknowledge an occurrence integral to the matter at hand.

I've staged this debate, creatively borrowed from Habermas, because both lines of thought compel me. Heidegger's transcendental argument leads us to richer reflections about the ontological dimensions of experience, conceptualization, and reason's various modalities-each can be said to be an event, and one that unfolds beyond the activity of any subject, whether you or me, Geist or God. And this enables us to historicize truth-claims without fully subjectivizing them. But note how Heidegger's account also aims toward a kind of adequacy, intellectual as opposed to practical (and recall that James countenances both). Heidegger offers a descriptive claim concerning relations that we describe as "true" and/or "false," and he provides evidence on its behalf, that is, other claims intended to establish its epistemic superiority; he knows something his rivals do not. The text thus seems oriented toward truth as adequation, even as it exposes one of the ways in which that conception is incomplete. Said otherwise, Heidegger's account seems to place itself along the continuum of absolute truth and absolute error, even as it re-opens the scene that "absolute" claims to arrange once and for all, thus allowing us to think anew about conceptual continua and how they come to be and pass away.

because a true word, everywhere, is a samizdat

"To write," Anne Michaels

25 I hope you have some sense of what I mean when I say: "philosophy's native realm is error," and why I continue to regard "truth" as integral to philosophy's Umwelt to the point that truth is a constitutive concern of the generation, presentation and reception of philosophical proposals. And I hope you will take both points as a shadow argument for the claim, "truth remains a philosophically interesting concept," even though I won't develop that position much further, or sufficiently specify in what (and toward what) that interest lies. (So far, I've only suggested that "true" and "useful" have some bearing upon one another.) Rather, I want to dig deeper into what I'm accepting when I say: philosophy's native realm is error. My fear isn't absolute error. How would I recognize getting everything wrong? Whatever falsifies some set of commitments cannot itself be simultaneously falsified and still do epistemic work. In other words, I 
need to trust whatever shows me I'm wrong if anything is to prove wrong. As Austin observes in Sense and Sensibilia: "Talk of deception only makes sense against a background of general non-deception.... It must be possible to recognize a case of deception by checking the odd cases against more normal ones" (11). Nor do I fear (or lament) the foreclosure of some absolute knowing. Although I cannot argue the point here, I take that foreclosure to open and preserve the figure of the human, and to set it within the expansions and contractions of a mortal relationality, a slice of which is epistemically oriented, and inescapably so. Moreover, an infinity in the grip of learning sounds, contra Hegel, more bad ass than bad. But here my concern is how philosophy bears the thought that its native realm is error.

My reply begins with an observation. Philosophy offers more than the content of its commitments. It also has, always has, its example. It has become customary to read Socrates as an image of philosophy, to find in his manner of address an exemplification of philosophical comportment. But when are such exemplifications not unfolding? Each philosophical text enacts philosophy and in so doing presents itself as an example of the examined life, a task that one cannot relinquish except in silence. (Try arguing that the unexamined life is worth living.) Not that each text exemplifies philosophy equally well, or even well, but every philosophical text is something of an apologia on behalf of philosophy.

I have come to think exemplification in terms of bearing. I have committed to "bearing" because it gathers so many moments integral to philosophy: (a) a general bearing or manner-for example, ironic, experimental, or systematic, what we might align with "voice" or "mood"; (b) the end toward which the writing bears (as one might bear north), say a better self, a therapeutic escape from philosophy, a post-theological culture, or, god help us, a post-secular one; (c) that which we bear (as in carry) when we write, namely texts, conversations, traditions, languages, but also economies and ecosocial webs of relation. Because that is a great deal to carry, a text must also endure involvements that threaten to drag it from its path. An academic career might lead one down a narrow line of inquiry or bind one to an unhelpful vocabulary; or, a latent nationalism might trap one in an exceptionalist history; or, an inherited metaphysics of the subject might re-entrench the euro-American modernity one aimed to exit. In such cases, philosophy proves unable to (d) bear, in the sense of endure, its historicity, or more generally its fatedness, that nest of unpenetrated causes that Emerson insists envelops us like a sea. Finally, philosophical texts, like all social acts, (e) bear consequences, perlocutionary and/or illocutionary, as a tree might bear a pitted fruit. Said otherwise, philosophical texts bear futures within which they are contributing variables, and these may or may not align with the ends toward which they deliberately bear.

Error behind it, error ahead, philosophy still offers its manifold bearings. What is its general manner? To what ends does it move? What does it carry enroute? How well does it endure the load? And with what results? Consider this list a diagnostic as well as a deliberative frame, questions to ask as we read and write philosophy with an eye on exemplification. But can a text exemplify philosophy in better and worse ways? And if so, in accord with what norms? I think several could and do come into play, including goodness, justice, and freedom. Here I would like to explore a less obvious standard, however. In English, one can say of another: they are a true friend, perhaps as one might describe a Freundschaft as echt or say of another un amigo de verdad or un vrai ami. 
Likewise, I might encourage someone to be true to themselves, which resonates, I think, with something like Und bleibt sich selbst treu. Phrases like this lead me to wonder whether and how philosophy might be true to itself, whether we can evaluate each philosophical text, qua apologia, as more or less true to philosophy. (Hegel asks of various gestalts-how does what purports to be knowledge appear under these conditions? I want to ask something similar of philosophical texts. How does philosophy appear here, and does it do so truly?)

This sense of "true" may strike you as odd. "Do you mean something like sincerity?" I don't think so. Sincerity involves agreement between stated and actual intentions, for example, when I compliment someone on a paper or invite them to dinner. In either case, one might wonder: is he sincere? Not that such questions cannot arise in philosophy. Some took delight in doubting the sincerity of Derrida's texts. (Were they serious?) As if he was putting us on, like Alan Sokal's "Transgressing the Boundaries: Towards a Transformative Hermeneutics of Quantum Gravity," which Sokal submitted to Social Text. But I am not imagining someone intentionally dissimulating. Rather, my thought is that philosophy, like friendship, has a kind of practical character with which one can be in or out of accord. That is, even among those sincerely pursuing philosophy, a kind of discord can resonate, which I want to term "sounding false."

30 Adorno has written: "Nothing is more unfitting for an intellectual resolved on practicing what was earlier called philosophy, than to wish, in discussion, and one might almost say in argumentation, to be right. The very wish to be right, down to its subtlest form logical reflection, is an expression of the spirit of self-preservation which philosophy is precisely concerned to break down" (70). Note the measure in question: unangemessener, unfitting, inappropriate, even unreasonable. The worry isn't error of a descriptive nature. It is not unfitting for philosophers to make mistakes. Shit happens. What is unfitting, out of step, is behaving in a way that runs counter to the practice in question. Philosophy, Adorno holds, promises something other than dogmatism in Kant's pejorative sense. The spirit of self-preservation prevents this, however, insofar as it leads one to cling to a position in order to win (or appear to win) argument. And in doing so, discord appears and one's efforts sound false relative to philosophy, to what it seeks and so asks of us.

31 Let me generalize from Adorno's remark. I imagine we have all been in arguments where one or more interlocutors either try to win the argument or prevent another from doing so. (One might term this social space "graduate school.") In such encounters, the thought of a collaborative advance away from absolute error and toward insight gives way to lawyer-like point scoring and theatrics. Polemics, which is a way of describing the general bearing of a text, carries some of this subversion into philosophical writing. "Genuine polemics approach a book as lovingly as a cannibal spices a baby," Walter Benjamin writes (460). They aim to foreclose a thought or position, and in a manner unconcerned with the richness on offer. In fact, a polemic only considers what enables refutation. "Polemics mean to destroy a book using only a few of its sentences," Benjamin adds. "The less it has been studied, the better" (460).

A general, hectoring bearing is apparent in polemics, which appear uninterested in open learning processes that might surprise. The polemicist is trying to win an argument in a zero-sum manner rather than pursue the conflict in a transformative one. And that, qua philosophy, sounds false, as if the issue were something like war pursued by other means rather than a transfigurative way of being historical by 
accounting for ourselves. More precisely, the polemicist does not allow the polemicized to account for itself, and that forecloses the appearance of something integral to philosophy, namely, an open exchange of views toward the end of some demonstrable advance.

Part of the conception I am exploring, one that brings the notion of truth and falsity to performativity-rather than leaving it to assertoric acts-derives from a line by Emerson that Cavell has made famous. Addressing those who refuse to venture their own thoughts (as well as those who might still try to), Emerson says: "This conformity makes them not false in a few particulars, authors of a few lies, but false in all particulars. Their every truth is not quite true. Their two is not the real two, their four not the real four: so that every word they say chagrins us, and we know not where to begin to set them right" (Essays: First Series 32). I've often wondered about the sense of "false" operating here, and about what precisely is being termed "false." If every word chagrins us, even another's use of numbers, the problem is more general than a failure to calculate properly or apply a concept according to a rule. And this is why it is so hard to right such characters. Going about it the wrong way, they get it wrong even when they get it right.

But what does that mean? The problem isn't ignorance, precisely, but conformity. I may not know the logic of a base ten number system, or even be aware than one is in operation, but that misstep leaves me naïve in a way that can be righted with a "did you know..." intervention. But if my basic bearing is conformist, I'll never look away from the cool kids long enough to find my own way. And in philosophy, that proves fatal.

Philosophy requires us to think for ourselves, to inhabit the turn of our "therefores," to render beliefs commitments, and to accompany commitments into the conversations in which they arose, ready for the reply of interlocutors, or the world's brush and bump should the working-touch of anticipation falter. Euthyphro's problem, or one of his problems, is that he isn't really there when the issue of what is pious or holy (to hosion) arises. Despite his purported expertise in theological matters, what Euthyphro has to say rings false in the mouth of someone concerned with the gods and their ways. (One might even say, he sounds impious, which is part of Plato's point, I take it-to contrast Euthyphro's faux piety with Socrates, who has been charged with atheism.) Imagine now a scene in which someone within philosophy "...dares not say I think, I am, but quotes some saint or sage," to recall another Emersonian line cherished by Cavell (Emerson, Essays: First Series 38). To be clear, the problem is not quotation; if anything, the absence of quotation sounds false in a practice that is historically saturated. The misstep lies with quoting in order to avoid being answerable. This avoidance, a kind of self-flight is what renders each remark counterfeit in a philosophical exchange. Just where philosophy was to be enacted something quite different appears.

When jargon and buzz words are used as jargon and buzz words, Emerson's position begins to sting. Jargon-driven or summary judgments of complex matters always resound with a kind of falseness. Think of references to broad schools of thought-poststructuralism, deconstruction, phenomenology, pragmatism, feminism-or politicaleconomic orders-liberalism, neo-liberalism, capitalism, socialism, communism. Whenever they are invoked as such, and left to stand as such, as if their referents were settled and our grasp of them thorough and uncontroversial, does anything definite come to mind? I don't think so, and so I wonder about how such remarks function. I wonder because such terms are surrounded by just the kind of discrepancies that 
Emerson would have us observe. Many understand these terms in many ways and the phenomena in question, by sheer size and dynamism, are wildly complex. And yet, that breadth is precisely what jargon suppresses, as if the complexity at hand were too much to bear, and the disagreement that accompanies any effort to corral it unwelcome. Conformity displaces us from the site where philosophy requires our presence. Jargon-as opposed to technical language-covers over those sites of differentiation that philosophy aims to endure in order to let something more than mere opinion order our conversations.

...don't ever, you said in the dream

think I've gone

"I Dreamed Again," Anne Michaels

I have been suggesting that being true to philosophy involves a kind of answerability, which I have elaborated as a bearing averse to conformity, jargon, and the polemic. But let's not forget where we began. Philosophy's native realm is error. Being true to philosophy thus entails, in part, remaining observant of philosophy's errancy, which is what I'd now like to consider, first by way of negation. As I understand it, thinking in observance of errancy is not exhausted by or even principally a matter of theoretically affirming falliblism-that only names the problem, and in the subjunctive; we might be wrong. My point is that we will be wrong and should conduct ourselves accordingly.

Almost certain that one's view will be surpassed, in part because we and the world change, in part because we play but a part and are thus partial, one should anticipate and court disagreement, extant and imagined. This not only tests one's commitments and the arguments behind them, possibly furthering them in unexpected directions, but announces, performatively: philosophy embraces disagreement. And that deepens the formal invitation that accompanies all writing qua address. You not only are welcome to the conversation but invited to disagree. (I have in mind something like Wittgenstein's Investigations, which, in the form of an imagined interlocutor, gives free reign to counter-intuitions, as well as the dialectic of Aristotle's Nicomachean Ethics, which engages all manner of positions, whether encoded in the Platonic dialogues or passed along by word of mouth.)

One should also embrace the value of error. "As soon as he sides with his critic against himself, with joy, he is a cultivated man," writes Emerson, who also wrote of the friend as a beautiful enemy (Conduct of Life 84). In this context, the thought is: one who advances our insight, even at the expense of what we had thought, bears a gift. Concretely, this entails a willingness to learn in public and to attest to having learned. Aristotle famously remarks, contesting Plato, that piety requires him to honor the truth above his friends. I am imagining something like Plato replying, with believable joy: "yes, the good does not answer to one idea, Aristotle, my friend," adding, "but tell me again how we determine which exemplars should be ours?"

I have allowed Plato this brief reply because not all disagreements are easily resolved on the basis of reflectively endorsed reasons. One might, therefore, leave certain disagreements suspended, at least until a convincing resolution announces itself. Heidegger's remarks on truth, like his remarks on freedom, leave one wondering how, if at all, they bear upon questions concerning the truth of beliefs and the freedom of agents. One can, after all, be ontologically released or freed into a life of bondage, and Gelassenheit amid the differential, abysmal scene of originary disclosure won't give one insight into the particular character of any-thing. But rather than take Heidegger's 
distance from these concerns to indicate either his superfluity or profundity, one might mark the distance as a matter for further thought, one that provokes us to think in a manner that doesn't abandon the ontological for the ontic or the ontic for the ontological, but maybe abandons, by working through it, that opposition.

Pausing in the thick of a contestation, I am trying to expand what is commonly regarded as the principle of charity, if for reasons somewhat obverse to Davidson's. Rather than presume the overall cogency of a rival language because one needs to do so in order to interpret it, I prefer to develop a rival view to its utmost because it may in fact advance philosophy in ways one did not initially grasp. This is akin to the kind of patience and generosity Judith Butler invokes in Giving and Account of Oneself, albeit within a broader, more epistemically ambitious scene. (Butler focuses on narrative recounting whereas I am equally interested in more formal-logical justificatory practices, the kind Habermas has in mind when he introduces Toulminesque argumentation into his discourse ethics.)

But maybe "charity" is too tame a term for the kind of active, creative inheritance I have in mind. The point is not to go easy on one's interlocutors-or hard-but to pursue possibilities with a kind of creative zeal even when they are not one's own. Fred Moten does something like this with Heidegger's conception of truth, which involves a groundless, opening horizon of disclosure that allows for a kind of anarchy of presencing, what Derrida regards as dissemination. As I understand it, Moten is concerned that the language of groundlessness may lead us to equalize differential fates, e.g. racial and/or socio-economic locations, thus obscuring how the ontologically contingent can still ruin, even end your life. In Black and Blur, he thus insists: "This false ubiquity of absence manifest as the proliferation of borders, must be radically misunderstood" (227). How? "And the trick, of course, is this refusal of border under border's constant imposition. In can't simply act as if and's segregation, however unreal, doesn't produce real effects" (227). Thinking, writing, and conversing in observance of error is not a zero-sum game, therefore, or a commitment to indeterminate negation. It rather essays possibilities, following out fault lines toward new disclosures it continues to pursue.

43 I am stressing the generative potential of charitable engagements because I would not have my emphasis on error dead end in a posture of perpetual suspicion or insouciant negation. Philosophy offered in observance of the discrepancies that surround it, and offered before the errancy that awaits, can be described as provisional, albeit not just epistemically. In a manner left to you, it may also belong to a stock of needed materials or supplies, something to chew on and convert into energy, perhaps even a measure taken before to deal with a need or contingency. I stress this because the observance I aim to enact is not simply dubious about what is on offer. Rather, it is a way of attending to and accompanying what presumably will provide some kind of working touch with the world.

Moten is again instructive. "Speak, so you can speak again" (152). I take the claim to be, address yourself in such a way that a reply, a response-from various quarters because the "you" is in the plural-is not only possible but invited as well as provoked. For instance (and building upon what I've said thus far), underscore that one also is responding, that response is how thought comes to pass. Moten finds something like this in Thorton Dial's (1928-2016) art. In certain cases, such as "History Refused to Die" (okra stalk and roots, clothing, collaged drawings, tin, wire, steel, Masonite, steel chain, 
enamel, and spray paint-2004), Dial reworks the already worked (including "art" and "artist"), says it anew in a way that initiates an experience without presuming to complete what emerges. Instead, that is left for another, although, if received in kind, one might be invited back.

draw your breath

on paper

"All We Saw," Anne Michaels

There is much more to say about the philosophical bearing I have been sketching, including the normative cast of such performances, particularly given the historicity of philosophy's character. But I want to end with a brief look at philosophy's place in the contemporary research university, particularly given the provisional nature of what philosophy has to offer.

If we take truth to be a radial category, one centered in paradigmatic cases, then, sociologically speaking, the fact of empirical inquiry is the paradigmatic case of truth. In such matters, "true" and "false" are terms of praise and blame for inductive generalizations made by and for experts on the basis of representative samples. And that is the sense of "true" that underwrites the knowledge whose production justifies the existence and operating budgets of research universities. Not that such institutions are satisfied with keeping such discoveries to expert communities. Increasingly, they champion a kind of public scholarship that requires experts to communicate results without really showing how they got there.

How easily does philosophy move within this figure of the public scholar? Not only does philosophy move rapidly to second-order questions presupposed by positive inquiry and its results, but its reflexivity requires it, simultaneously, to reflect on its claims and their mode of presentation. It thus can never simply share its "results" and have them remain philosophical. Philosophy has to show its work if it is to remain philosophical. "God exists" can be a cogent sentence in various settings. But left on its own, it fails to prove philosophical. It could be a prayer, or a categorical refusal to explore a matter openly. For it to be philosophical, it must be enacted within a reflexive practice of reflection and justification of one sort or other, and if what I've said here holds, one that observes its intimacy with error.

Consider now my turn to bearing as the front foot of philosophy, as the deepest source of whatever provisions it provides. It is difficult to square this with knowledge production, particularly if one is also expected to publicize one's results. But maybe this shouldn't surprise us. Plato's legacy is Socrates more than any thesis, and the dialogue form more than any doctrine. While there are few remaining Cartesians, the idea of something like a series of meditations, particularly when combined with objections and replies, remains vibrant. And didn't Hegel provide Marx with immanent critique and determinate negation, and thus enable the undoing of his own Philosophy of Right? When I read Du Bois, what startles me the most is the range of reflections he brings to the color line: history, sociology, fiction, autobiography, music, and political philosophy. So too Beauvoir-something like genuine, historical thought vibrates in the concreteness of conceptions that nevertheless resist positivism. Each of these author's leads with their example, which overrun their results.

49 Let me close, therefore, with a conundrum. How does philosophy engage a broader public while remaining true to itself? How does one make one's bearings apparent? I think the figure of the expert peddling results misses the mark. I would rather remain 
Socratic in the sense that everything we do, like Plato's Socrates, is also an image of philosophy, and one haunted by ignorance. Philosophy's native realm is error. It is born there, and error is where it lives. But even as it falls prey to error, its example admits of praise and blame, such as being true to philosophy, or, in the name of philosophy, sounding false.

\section{BIBLIOGRAPHY}

Adorno, Theodor. Minima Moralia. Translated by E.F.N. Jephcott, New Left Books, 1974.

Austin, J.L. Sense and Sensibilia. Edited by G. J. Warnock, Oxford UP, 1962.

Benjamin, Walter. Selected Writings. Edited by Marcus Bullock and Michael W. Jennings, vol. 1, The Belknap Press of Harvard UP, 1996.

Emerson, Ralph Waldo. The Collected Works of Ralph Waldo Emerson: Nature, Addresses, Lectures. Edited by Joseph Slater and Robert E. Spiller, Harvard UP, 1971.

---. The Collected Works of Ralph Waldo Emerson: Essays: First Series. Edited by Joseph Slater, Alfred Ferguson, Jean Ferguson Carr, Harvard UP, 1979.

---. The Collected Works of Ralph Waldo Emerson: Essays: Second Series. Edited by Alfred R. Ferguson, Jean Ferguson Carr, and Joseph Slater, Harvard UP, 1983.

---. The Collected Works of Ralph Waldo Emerson: The Conduct of Life. Edited by Barbara Packer, Joseph Slater, Douglas Emory Wilson, Harvard UP, 2003.

Grumet, Robert S. Manhattan to Minisink: American Indian Place Names in Greater New York and Vicinity. U of Oklahoma P, 2013.

James, William. Pragmatism \& The Meaning of Truth. Harvard UP, 1978.

Michaels, Anne. All We Saw: Poems. Alfred A. Knopf, 2017.

Moten, Fred. Black and Blur. Duke UP, 2017.

\section{ABSTRACTS}

The essay explores multiple senses of "true," arguing that truth not only has a performative sense, but that certain performances can themselves be true as when a friend is a true friend. Taking that thought in a metaphilosophical direction, the essay also argues that writing can be true to philosophy or sound false on those terms.

\section{INDEX}

Keywords: truth; performativity; Ralph Waldo Emerson; Stanley Cavell; Martin Heidegger 


\section{AUTHOR}

\section{JOHN T. LYSAKER}

John Lysaker is William R. Kenan Professor of Philosophy at Emory University. He works in aesthetics, philosophical psychology, and ethics, drawing from multiple traditions and historical periods. Recent books include After Emerson (Indiana UP, 2017) and Philosophy, Writing, and the Character of Thought (U of Chicago P, 2018). Twists of Fate: Hope, Trust, and Forgiveness, a perfectionist approach to normative ethics, should appear in 2022. 